\title{
Son of Sevenless Homolog 1
}

National Cancer Institute

\section{Source}

National Cancer Institute. Son of Sevenless Homolog 1. NCI Thesaurus. Code C116311.

Son of sevenless homolog 1 (1333 aa, $152 \mathrm{kDa}$ ) is encoded by the human SOS1 gene.

This protein is involved in the mediation of guanine nucleotide exchange for RAS superfamily proteins. 